\title{
Faktor-Faktor Yang Mempengaruhi Minat Masyarakat Dalam Usaha Beternak Babi Di Desa Petak Bahandang
}

\author{
Seth Miko ${ }^{1}$, Susan Daniel ${ }^{1 *}$, Yesni Nopy ${ }^{1}$ \\ ${ }^{1}$ Program Studi Pendidikan Luar Sekolah, Universitas Palangka Raya, Indonesia \\ *email: susan.daniel@fkip.upr.ac.id
}

Diterima: 27-10-2021; Diperbaiki:01-12-2021; Disetujui:10-12-2021

\begin{abstract}
ABSTRAK
Pengembangan usaha peternakan harus disesuaikan dengan potensi daerah, ketersediaan pakan, dan kondisi sosial budaya untuk meningkatkan tingkat keberlanjutan dari usaha tersebut. Beternak babi merupakan salah satu usaha mata pencaharian masyarakat dalam memenuhi kebutuhan hidup dan menambah pendapatan rumah tangga. Penelitian ini dilaksanakan di Desa Petak Bahandang, Kabupaten Gunung Mas yang memiliki banyak peternak babi. Penelitian ini bertujuan untuk mengetahui faktor-faktor yang mempengaruhi minat masyarakat dalam usaha beternak babi. Penelitian ini merupakan penelitian lapangan dengan metode penelitian yang digunakan adalah metode deskriptif kualitatif. Hasil dari penelitian adalah terdapat beberapa faktor yang mempengaruhi minat masyarakat dalam beternak babi, yaitu kondisi lingkungan, modal awal, ketersediaan pakan, pemasaran, dan jaminan harga.
\end{abstract}

Kata Kunci: ternak babi, minat masyarakat, pendapatan rumah tangga

\section{PENDAHULUAN}

Usaha merupakan upaya yang dilakukan untuk mendapatkan keuntungan. Dalam upaya untuk mendapatkan keuntungan dan memenuhi kebutuhan sehari-hari biasanya seseorang atau sekelompok masyarakat melakukan berbagai macam usaha. Seperti kegiatan jual beli, dan memanfaatkan sumberdaya alam untuk dijadikan lahan usaha, berkebun, bertani, berternak, dan lain sebagainya.

Ternak babi merupakan salah satu spesies yang dapat berkembang biak dengan cepat, pakan bisa didapat dari segala jenis sumber pakan serta memiliki nilai produksi yang relatif tinggi di pasaran. Dilihat dari segi teknik dan ekonomi, usaha ternak babi tidak terlalu memiliki kendala. Dalam hal beternak babi perlu dipertimbangkan faktor dukungan sosial bahwa sebagian besar penduduk di Indonesia mayoritas beragama Islam. Maka dari itu, sangat perlu diperhatikan pengembangan usaha ternak babi pada lingkungan tersebut. (Alzamakhsyari, 2015).

Program ternak babi merupakan program usaha yang diutamakan di Kabupaten Gunung Mas yang bertujuan untuk meningkatkan kemandirian dan pendapatan tambahan bagi rumah tangga. Desa Petak Bahandang mayoritas warganya berprofesi sebagai petani, pedagang, dan peternak. Kegiatan beternak merupakan suatu hal yang biasa dilakukan oleh masyarakat, salah satunya adalah beternak babi. 
Ternak babi merupakan jenis ternak yang sangat potensial untuk dikembangkan oleh rumah tangga di desa Petak Bahandang, dalam pelaksanaannya masih banyak kendala yang dihadapi oleh masyarakat.

Tujuan dari penelitian ini adalah untuk mengetahui faktor-faktor yang mempengaruhi minat masyarakat dalam usaha beternak babi di Desa Petak Bahandang.

\section{METODE PENELITIAN}

Penelitian yang dilakukan adalah penelitian bersifat kualitatif dengan menggunakan metode deskriptif kualitatif.

Penelitian dilakukan di Desa Petak Bahandang kecamatan Kurun kabupaten Gunung Mas, dilaksanakan pada bulan Juli-Agustus 2021. Sempel adalah peternak babi di Petak Bahandang sebanyak 20 orang.

Pengumpulan data yang digunakan yaitu dengan melakukan observasi, wawancara, dan dokumentasi. Teknik analisis data dengan menggunakan Teknik analisi deskriptif kualitatif.

\section{HASIL DAN PEMBAHASAN}

\section{Beternak Babi di Desa Petak Bahandang}

Program ternak babi merupakan program yang diutamakan di kabupaten Gunung Mas yang bertujuan untuk meningkatkan kemandirian dan pendapatan tambahan bagi rumah tangga berdasarkan objek wilayah dan jumlah penduduk. Beternak babi merupakan salah satu mata pencaharian sebagian masyarakat di desa Petak Bahandang dalam menambah pendapatan rumahtangga. Kontribusi usaha ternak babi terhadap pendapatan rumahtangga sebesar 20,70\%. (Wunda, et al. 2014)

Masyarakat di desa Petak Bahandang yang mayoritas penduduk beragama Kristen, ternyata tidak semua masyarakat melakukan kegiatan beternak babi. Hal tersebut dikarenakan, sebagian masyarakat lebih memilih usaha lain seperti berkebun, berbudidaya ikan, dan sebagainya. Masyarakat di desa Petak Bahandang yang beternak babi berdasarkan hasil observasi/survei dilapangan terdapat sebanyak 20 kepala keluarga. Ternak babi yang dipelihara bervariasi jumlahnya, ada yang memelihara 1-7 ekor per kepala keluarga. Jenis kendang yang digunakan hampir semua menggunakan bahan baku kayu. Jenis ternak babi yang dipelihara adalah jenis babi lokal (kampung), dan babi bali.

\section{Faktor-Faktor yang Mempengaruhi Minat Masyarakat dalam Beternak Babi}

Minat merupakan suatu keinginan seseorang terhadap sesuatu atau objek tertentu. Tanggapan masyarakat dari pertanyaan yang diberikan mengenai apa saja yang mempengaruhi minat masyarakat dalam usaha beternak babi di desa Petak Bahandang kecamatan Kurun kabupaten Gunung Mas, antara lain adalah: kondisi lingkungan, modal awal, ketersediaan pakan, pemasaran, dan jaminan harga. 
Desa Petak Bahandang yang mayoritas masyarakat beragama Kristen menjadikan wilayah ini sangat bisa untuk melakukan kegiatan beternak babi. Walaupun demikian, masyarakat harus memperhatikan kondisi sosial agar tidak terjadi perselisihan. Faktor kondisi lingkungan akan berdampak terhadap produktivitas. Ukuran kandang, luas kendang, dan kelembapan harus diperhatkan. Usaha beternak babi juga harus mempertimbangkan mengenai masalah penanganan limbah. Limbah yang tidak dikelola dengan baik akan menimbulkan masalah lingkungan seperti polusi udara (bau) yang dapat mengganggu kenyamanan masyarakat yang bertempat tinggal di wilayah sekitar.

Dalam memulai suatu usaha haruslah didukung dengan berbagai faktor, salah satunya adalah dalam hal modal usaha. Modal yang harus diperhatikan yaitu modal untuk pembuatan kendang. Modal pembuatan kendang bervariasi tergantung ukuran, dan jenis bahan baku yang digunakan. Pemilihan jenis bahan baku pembuataan kendang sangat mempengaruhi keawetan atau masa pakai kandang. Dari hasil wawancara dengan masyarakat di desa Petak Bahandang mendapatkan data biaya pembuatan kandang berkisar antara Rp300.000 - Rp1.000.000 tergantung ukuran dan bahan baku yang digunakan. Selain biaya kandang, modal biaya pembelian bibit ternak babi juga harus diperhitungkan. Harga bibit ternak babi berkisar antara Rp750.000 - Rp1.200.000. Pemilihan bibit juga sangat berpengaruh terhadap kualitas ternak babi. Oleh karena itu, dalam hal modal usaha harus diperhitungkan. Komponen utama dalam suatu usaha khususnya usaha ternak babi, yaitu biaya. Biaya merupakan korbanan yang dikeluarkan oleh peternak selama menjalankan usaha. (Warouw dkk, 2014)

Ketersediaan pakan dalam beternak babi merupakan faktor pendukung. Tersedian pakan organik yang terdapat di wilayah sekitar dapat mengurangi biaya produksi. Pakan yang tidak tersedia dapat menambahan biaya produksi. Harga pakan berpengaruh nyata terhadap produksi. Sesuai hasil penelitian Hardyastuti (2011) bahwa biaya pakan dalam usaha ternak babi berkisar antara 70-80 \% dari total biaya produksi. Peternak perlu menggunakan bahan pakan yang murah. Dalam hal ini, pemanfaatan bahan pakan murah pada level yang tepat akan memberikan keuntungan ekonomi. Ariana et al (2014). Pemilihan pakan yang tepat sangat menentukan terhadap pertumbuhan ternak. Pakan adalah salah satu faktor penting dalam usaha ternak babi. (Hardyastuti, 2011). Periode penggemukan ternak babi membutuhkan komposisi pakan yang berkualitas baik yang mengandung energi, protein, mineral, vitamin dan air (Sinaga dan Martin, 2010).

Ketersediaan pakan ternak babi di desa Petak Bahandang bisa dikatakan mudah didapat dan cukup terpenuhi. Pakan ternak yang digunakan berupa tanaman keladi dan sejenisnya, sisa-sisa makanan, nasi kering, dan juga dedak, meskipun sebagian dari bahan pakan tersebut didapat dengan cara membeli. Ketersedian pakan tersebut masih bisa memenuhi kebutuhan pakan ternak babi skala rumah tangga.

Berkaitan dengan faktor pemasaran, dimana saingan akan daging babi sangat marak terjadi karena babi mudah untuk dikembangbiakkan dan dipasarkan 
dikalangan masyarakat dan desa tetangga, hal ini menjadi faktor penghambat yang menjadi bahan pikiran dari pemerintahan desa dan juga masyarakat desa yang bergerak dalam usaha peternakan babi.

Strategi pemasaran dapat dicapai dengan tepat dan terbaik untuk diterapkan, salah satunya produsen dapat melihat dari faktor marketing mix atau pemasaran. Marketing mix menjadi hal yang penting karena merupakan salah satu pokok pertimbangan konsumen dalam melakukan keputusan pembelian suatu produk (Herawati,2013).

Jaminan Harga/penjualan yang tinggi menjadi faktor penentu dalam keberlangsungan ternak babi. Dengan jaminan harga yang memadai menjadikan masyarakat semangat untuk melakukan kegiatan beternak.

\section{KESIMPULAN}

Faktor-Faktor yang Mempengaruhi Minat Masyarakat dalam Beternak Babi di Desa Petak Bahandang, yaitu kondisi lingkungan, modal awal, ketersediaan pakan, pemasaran, dan jaminan harga.

\section{DAFTAR PUSTAKA}

Alzamakhsyari, L.A. (2015). Analisis Potensi Ternak Babi di Indonesia. Laporan Praktikum.

Ariana, I.N.T., A.W. Puger., A.A. Oka dan N.I.P. Sriyani. 2014. Analisis Ekonomi Usaha Ternak Babi Dengan Pemberian Sekam Padi Dalam Ransum Yang Mengandung Limbah Hotel. Jurnal Ilmiah Peternakan 17(2) : 71-74

Bintarto, R. Prof. Dr. (2011). Interaksi Desa-Kota. Yogyakarta: Ghalia Indonesia BKKBN. (1985). Pelembagaan dan Pembudayaan NKKBS. Jakarta: PUSDIKLAT Tenaga Program BKKBN.

Brown, L. Hindmarsh, R. Mcgregor, R. (2001) Pemanfaatan dan produksi daging babi di Bali. Jurnal online.tata cara pengolahan daging babi bali

Hardyastuti, S. 2011. Kajian Biaya Produksi pada usaha Peternakan babi. Jurnal Sosek Peternakan Unibraw Malang. 12(1): 136-143

Rangkuti, F. 2009. Analisis SWOT Teknik Membedah Kasus Bisnis. Reorientasi Konsep Perencanaan Strategis untuk Menghadapi Abad 21. Jakarta: Gramedia Pustaka Utama.

Rusadi, Dwiko Septiyadi. 2015. Skripsi: Pengaruh Sosial Ekonomi Terhadap Minat Pemuda dalam Beternak Sapi Potong di Desa Bonto Cinde Kecamatan Bissappu Kabupaten Bantaeng. Makasar: Universitas Hasanuddin

Sinaga S, dan S. Martini. 2010. Pemberian berbagai dosis curcuminoid pada ransum babi periode starter dan efisiensi ransum. Jurnal Ilmu Ternak. 1(10): 95-101

Soeharto, (2015) Manajemen Proyek pengelolaan babi (Persiapan, Pelaksanaan, Pengelolaan). Jakarta: Erlangga.

Utomo. (2004). "Pengembangan Ternak Babi Lokal di Indonesia" WARTAZOA Vol. 25 No. 1 
Warouw ZM, Panelewen VVJ, Mirah AD. 2014. Analisis usaha peternakan babi pada perusahan "Kasewean" Kakaskasean II Kota Tomohon. Jurnal Zootek 34(1): 92-102

Wunda, A.B, Kaban, A, dan Nalle,A.A. 2014. Kontribusi Usaha Ternak Babi Terhadap Pendapatan Rumahtangga Peternak di Kecamatan Wewewa Barat Kabupaten Sumba Barat Daya. Jurnal Nukleus Peternakan (Desember 2014), Volume 1, No. 2: 100 - 107. ISSN : 2355-9942 